\title{
Dynamic simulation applied to personnel's productivity in the filling water jugs process
}

\section{Simulación de la productividad del personal en el proceso de llenado de garrafones de agua mediante simulación dinámica}

\author{
CALDERÓN-PALOMARES, Luis Antonio †*, DEL ÁNGEL-CORONEL, Oscar Andrés, GONZALEZ- \\ SOBAL, Martín and SOLÍS-JIMENEZ, Miguel Ángel
}

Tecnológico Nacional de México-Instituto Tecnológico Superior de Huatusco. Programa de Maestría en Ingeniería. Av. 25 Poniente No. 100 Colonia Reserva Territorial C.P. 94100, Huatusco Ver. México.

ID $1^{\text {st }}$ Author: Luis Antonio, Calderón-Palomares / ORC ID: 0000-0001-9846-5567, Researcher ID Thomson: N-62592018, CVU CONACYT ID: 238274

ID $1^{\text {st }}$ Coauthor: Oscar Andrés, Del Ángel-Coronel / ORC ID: 0000-0002-0848-907X, CVU CONACYT ID: 226585

ID $2^{\text {nd }}$ Coauthor: Martín, Gonzalez-Sobal / ORC ID: 0000-0003-0038-8319, Researcher ID Thomson: N-6243-2018, CVU CONACYT ID: 463431

ID $3^{\text {rd }}$ Coauthor: Miguel Ángel, Solís-Jimenez / ORC ID: 0000-0002-8125-0989, CVU CONACYT ID: 94216

DOI: $10.35429 / J E S .2019 .4 .3 .26 .34$

Received March 06, 2019; Accepted June 13, 2019

\begin{abstract}
Companies require tools for analysis and decision-making, so simulation tools present a competitive advantage to be able to evaluate situations and scenarios that allow establishing properly structured action plans and gather all available information on resources, processes, and elements involved in the operation dynamics. The dynamic simulation offers an integrating vision that allows seeing the impact of external variables on the internal variables of interest to be evaluated as a time function with a systemic approach. This paper aims to visualize and detect the dynamics of the interrelationships that occur between the problems that arise in the process of filling water jugs of a purifying company and the problems at the organizational level, to assess the impact on Productivity. First, the pertinent information was collected in the company together with the opinion of experts in the corresponding areas and based on this develop a model with the main variables of operation of the process and personnel's operational performance that makes up the production system of the company under study. Subsequently, the model was validated to analyze it and draw conclusions that allow us to establish proposals for improvement.
\end{abstract}

Productivity, Dynamic Simulation, Human Resource

\begin{abstract}
Resumen
Las empresas requieren de herramientas para el análisis y toma de decisiones, por lo que la simulación, presenta una ventaja competitiva para poder evaluar situaciones y escenarios que permitan establecer planes de acción debidamente estructurados y que reúnan toda la información disponible de los recursos, procesos y elementos que intervienen en la dinámica de operación. La simulación dinámica ofrece una visión integradora que permite evaluar en función del tiempo, con un enfoque sistémico, el impacto de las variables externas sobre las variables internas de interés. En el presente trabajo se busca visualizar y detectar la dinámica de las interrelaciones que existen entre los problemas que se presentan en el proceso de llenado de garrafones de agua y los problemas a nivel organizacional, para evaluar la afectación sobre la productividad del recurso humano. Como primer paso se recabo la información pertinente en la empresa en conjunto con la opinión de expertos en las áreas correspondientes y en base a esto se procedió a elaborar un modelo con las principales variables de operación del proceso y de actuación del personal operativo que conforman el sistema productivo de la empresa bajo estudio. Posteriormente se realizó la validación del modelo para analizarlo y extraer conclusiones que permitan establecer propuestas de mejora.
\end{abstract}

Productividad, Simulación Dinámica, Recurso Humano

Citation: CALDERÓN-PALOMARES, Luis Antonio, DEL ÁNGEL-CORONEL, Oscar Andrés, GONZALEZ-SOBAL, Martín and SOLÍS-JIMENEZ, Miguel Ángel. Dynamic simulation applied to personnel's productivity in the filling water jugs process. Journal-Economic Systems. 2019. 3-4: 26-34

\footnotetext{
* Correspondence to author (email: luiscp@ netscape.net)

$\uparrow$ Researcher contributing as first author.
} 


\section{Introduction}

In small manufacturing enterprises, the need for performance-enhancing management should be emphasized. The control system must effectively show the key business operations that must be established in a way that is understandable, comprehensive and flexible enough to adapt to the specific needs of each individual company and the changing market (Singh, 2012). The dynamic strategy of a small business means that these companies are reviewing their decisions more frequently than larger companies (Madani Alomar, 2014). The main challenge is to provide better services. This should be a priority for all SMEs to create an agile and dynamic service design (Nader Nada, 2015).

This paper analyzes the productivity in the water jug filling operation in a purification company by developing a dynamic model, considering the links in the supply chain and the working environment of the company. Initially called the industrial dynamics, the field developed from the work of Jay W. Forrester (Angerhofer, 2000). Industrial dynamics describes the application of feedback concepts to social systems with a focus on corporate policy design (Forrester, 1968). System dynamics is a method that helps us improve learning in complex systems, where computer simulation modeling enables us to learn about dynamic complexity, understand sources of policy resistance, and design more effective policies (Sterman, 2000). The main advantages of system dynamics include a means to understand the system by identifying relationships between factors, the use of a structured model that allows decision makers to simulate the current functioning of the system and explore opportunities for improvement, and assistance to decision makers in predicting system sustainability performance metrics (Hao Zhang, 2013).

\section{Justification}

The water purification company Cristal, located in the central zone of the State of Veracruz, does not have an adequate control in its supply chain of water jugs, which results in unnecessary expenses, bad planning and projection of its sales, in addition to a bad management of the personnel which makes the labor climate a variable that impacts the productivity.

\section{Problem}

Catalogued according to the number of employees as well as its extension as a SME (Small and Medium Enterprises), Cristal Water Purification Company does not have a reliable tool for planning and controlling its supply chain, as well as determining the main variables it must control in order to boost its productivity. Therefore, the company's current problem consists of a shortage in its filling line as well as low productivity. Considering also the existence of an inadequate work environment that contributes to a decrease in productivity.

\section{Hypothesis}

The dynamic simulation provides a tool for a better analysis in the policies of production systems in the water purification company Cristal and helps in decision making for optimal control and management of the main variables that affect their productivity.

\section{Objectives}

\section{General Objective}

To elaborate a model with the support of dynamic simulation, which allows to improve the productivity and to support in the decision making for the best control of the supply chain in the area of filling jugs in the Cristal purifying company.

\section{Specific objectives}

- $\quad$ To develop a dynamic simulation model that represents the current behavior of the company.

- To validate the model and analyze the critical points or areas of opportunity to establish improvement actions.

\section{Theoretical Framework}

System dynamics is a method used to face complex systemic problems with the combination of qualitative and quantitative methods, based on feedback theory and with the strong influence of general systems theory and mathematical modeling, based on differential equations (Forrester, 2006). 
Initially, a systemic model of the problem is built, then it is projected in simulation technologies to validate and verify the approach and reality of the problem under study (Forrester, 1996).

System models are characterized by considering an object of study as a dynamic system. They possess a certain internal structure and are also affected by external conditions that influence the model. These models serve to help in decision-making and in the formulation of policies for improving the systems. (Forrester, 1989).

\section{Causal Diagrams}

Causal diagrams are a key tool within system dynamics modeling, a tool that serves to identify feedback loops and internal system behavior. They illustrate the feedback structure of the system and serve to identify the mind maps of the structures made up of various elements, as well as reveal individual behavior patterns (Chae and Olson, 2007).

Causal diagrams are also useful in the elaboration and understanding of models, in the construction of dynamic hypotheses, and they facilitate the obtention and transmission of knowledge. Their conceptualization starts from the simple definition of causality that represents the effect (immediate or delayed) that one variable may have on the other (Sterman, 2000). Causal diagrams are made up of variables that are joined together by means of arrows that determine the causal relationship between them.

The base variable (or the one that causes the effect) is positioned at the base of the arrow and is the one that produces the effect on the variable at the tip of the arrow (target variable). The categorization of the effect or causal relationship is defined by a polarity symbol (+ or -) that depends on whether the effect that the base variable causes on the target variable is directly proportional $(+)$, or on the contrary, if the effect is inversely proportional (-). Once the variables, causal relations and polarities of the whole scheme have been identified, the cycle or feedback identifiers are defined. These are determined from a curved arrow in the direction of the evolution of the cycle and can be positive or reinforcing $(\mathrm{R})$.
A reinforcement cycle is obtained if, when starting positively from a base variable and following the effect on all the variables involved in the cycle, it returns to it in a positive way, or what is the same, when the product of all the polarities immersed in the cycle results in a positive value (Sterman, 2000).

In the same way, negative cycles or of balance (B) can be identified when starting positively from a base variable and then it is returned after crossing all the cycle in a negative way, or, consequently, when the product of all the polarities of the cycle gives as result a negative symbol (-). Another important aspect that can be identified with this type of structure is the implicit delays within the system that greatly affect real phenomena. As the characterization of the variables is done one by one, it is easy to see when the effect is not immediate and this helps notably in the final formulation of the model (Chandler and Boutilier, 1992).

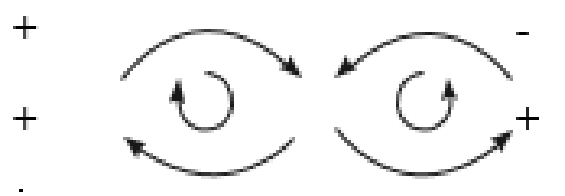

Figure 1 Example of Causal Diagram (Births $\mathrm{R}$ population B Deaths)

Source: (Sterman. 2000)

Figure 1 (Sterman, 2000) illustrates an example of a causal diagram to model the effect of the variable births and deaths on the population. The example identifies two feedback loops, one positive and one negative, affecting the population of a locality.

For example, in a cash flow financial system, one must understand how payment delays affect subsequent investments and how financial variables can be connected to each other. The formation of structures of this type has defined well-known archetypes in the literature. These are those structures and accepted hypotheses that reveal behaviors commonly found in real life. Sterman, J. (2000). 


\section{Flow and level diagrams}

Flow and level diagrams are graphic representations used to develop a detailed quantitative analysis of systemic structure and behavior, qualitatively represented from the causal diagrams. In system dynamics, causal diagrams are transformed into flow and level diagrams to study and analyze the system in a quantitative way. Such diagrams are highly used in economics and business, and related fields, because their variables can be easily distinguished between flows and levels. These differ mainly from the units of measurement and their behavior in the system. Olson D. (2007).

Level variables (symbolized by squares) are state variables, or what is the same, measured in a specific time. They represent the existing amount of a variable of interest at a given moment in time that could have been accumulated in the past. Additionally, levels are entities that are accumulated over time by inflows or decreased by outflows. Levels can only be affected by those flows and mathematically a level can be seen as an integration of the flows over time, where the inflows and outflows would have a positive and negative effect on the level respectively. (Swatman, 1997)

A flow variable is measured per unit of time and can be considered as rates within the simulation scheme. They change the level over time, they can be classified as input and output flows, which add the level or subtract the level respectively. Flows are measured over a certain time interval as number of births per day, or number of students per year. For example, in accounting, a tier may symbolize the value of an asset in a given period, while a flow would indicate the possible transactions such as sales, purchases, income or expenditures that are made from period to period in the system. Forrester, J.W. (1996).

\section{Study of inventory control based on system dynamics}

System dynamics is an appropriate methodology to study inventory control in a supply chain, because it can capture the feedback loops embedded in the chain and to model the nonlinearities of the system. (Baganha, 1998).
Likewise, the methodology allows for the definition, integration and quantitative formulation of the multiple activities associated with the inventory problem, such as the relationship between production and sales. And the causal diagrams make it possible to clarify the internal dynamics of the system and the computer simulations and to propose possible scenarios to identify emerging behaviors of the system. (Feng Yang, 2009).

\section{Research Methodology}

As a first step, we analyze the company's operations using a black box diagram, in order to determine, together with the company, the type of variables that interact in the organization. Later, the variables used to build the simulation model are classified, establishing the causal hypotheses that govern the system. Finally, the simulation model is developed in the STELLA software for validation and, if validated, the corresponding experimentation is carried out.

\section{Type of research}

The type of research implemented in this work is longitudinal, explanatory, and experimental with quantitative data. The sources used for the project were based on:

- $\quad$ Historical records of the company.

- Interviews with operators and managers of the organization.

Literature and simulation work previously done in system dynamics.

\section{Results}

Two black box diagrams were developed for business organization and shortage of jugs (Figures 2 and 3).

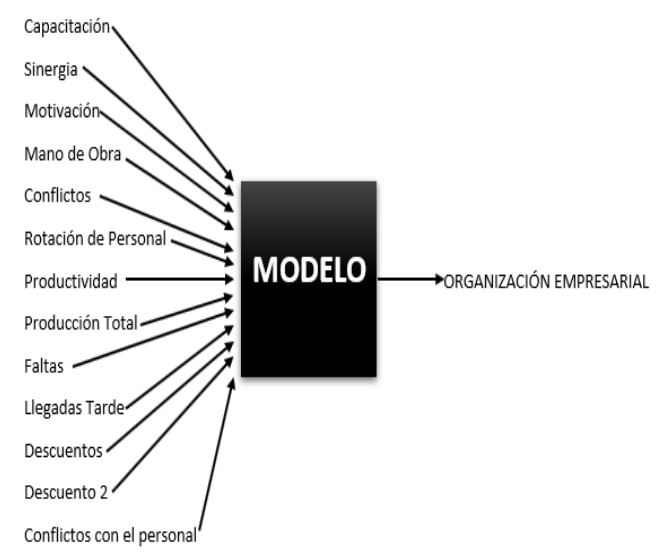

Figure 2 Black Box diagram for business organization Source: Prepared by the authors 


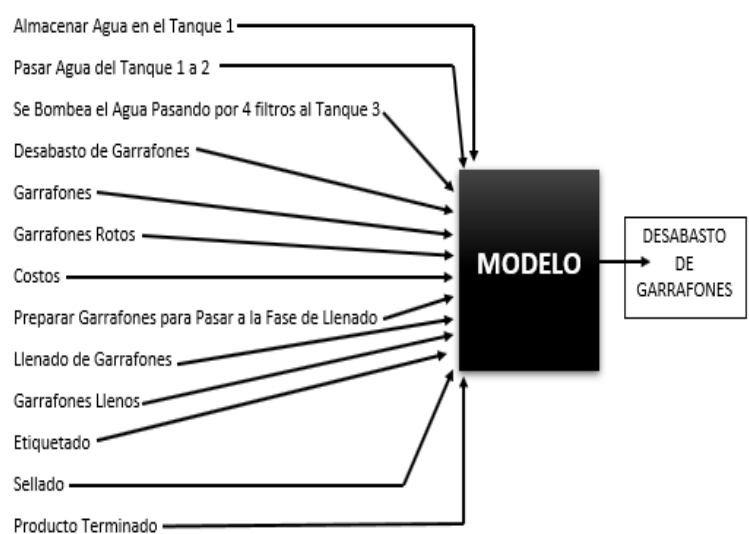

Figure 3 Black Box diagram for jug shortage Source: Prepared by the authors

\section{Variables}

Below are the variables that are considered relevant to the dynamic simulation model of the company.

\section{JUG SHORTAGE}

\section{JUGS}

BROKEN JUGS

COSTS

PREPARING JUG FOR FILLING

JUG FILLING

FULL JUGS

\section{LABELLING}

SEALED

\section{DAILY PRODUCTION}

PRODUCTIVITY

TRAINING

MOTIVATION

$\mathrm{MO}=\mathrm{LABOUR}$

SYNERGY

STAFF ROTATION

STAFF CONFLICT

LATE ARRIVALS

DISCOUNTS

ABSENCE

\section{Equations}

The equations considered in the STELLA's model are as follows:

$\begin{array}{llllll}\text { CONFLICTOS_CON_EL_PERSONAL } & & (\mathrm{t}) & & = \\ \text { CONFLICTOS_CON_EL_PERSONAL } & (\mathrm{t} & - & \mathrm{dt}) & +\end{array}$ $\begin{array}{lllll}\text { CONFLICTOS_CON_EL_PERSONAL } & (\mathrm{t} & - & \mathrm{dt}) & + \\ (\text { CONFLICTOS }) & & & & \text { dtINIT }\end{array}$ CONFLICTOS_CON_EL_PERSONAL $=$ CONFLICTOS INFLOWS:

CONFLICTOS $=($ INT $\quad($ RANDOM $(0,3))+$ INT $($ LLEGADAS_TARDE*18/100))+DESCUENTOS

ETIQUETADO $(\mathrm{t})=$ ETIQUETADO $(\mathrm{t}$ - $\mathrm{dt})+($ Paso_1 - Paso_2 $)$ $*$ dIINIT ETIQUETADO $=0$

$$
\begin{aligned}
& \text { TRANSIT TIME }=1 \\
& \text { INFLOW LIMIT }=\text { INF } \\
& \text { CAPACITY }=\text { INF }
\end{aligned}
$$

INFLOWS:

Paso_1 $=$ CONVEYOR OUTFLOW OUTFLOWS:

Paso_2 = CONVEYOR OUTFLOW

GARRAFONES_LLENOS $(\mathrm{t})=$ GARRAFONES_LLENOS $(\mathrm{t}$ $\mathrm{dt})+($ LLENADO_DE_GARRAFONES - Paso_1) $*$ dtINIT GARRAFONES_LLENOS $=0$

$$
\begin{aligned}
& \text { TRANSIT TIME }=1 \\
& \text { INFLOW LIMIT }=800 \\
& \text { CAPACITY }=1000
\end{aligned}
$$

INFLOWS:

LLENADO_DE_GARRAFONES=PREPARAR_GARRAFON ES_PARA_PASAR_A_FASE_DE_LLENADO

OUTFLOWS:

Paso_1 = CONVEYOR OUTFLOW

$\operatorname{SELLADO}(\mathrm{t})=\operatorname{SELLADO}(\mathrm{t}-\mathrm{dt})+($ Paso_2 $-\operatorname{SALIDA}) * \mathrm{dt}$ INIT SELLADO $=0$

$$
\begin{aligned}
& \text { TRANSIT TIME }=1 \\
& \text { INFLOW LIMIT }=\text { INF } \\
& \text { CAPACITY }=\text { INF }
\end{aligned}
$$

INFLOWS:

Paso $\_2$ = CONVEYOR OUTFLOW

OUTFLOWS:

SALIDA $=$ CONVEYOR OUTFLOW

CAPACITACION $=(18-(\operatorname{RANDOM}(0,1) * 18) / 100) * 5.55$

COSTOS $=$ GARRAFONES_ROTOS $* 67.28$

DESABASTO_DE_GARRAFONES $=$ INT $(\operatorname{RANDOM}(1,10))$

DESCUENTOS $=(($ FALTAS $* 18) / 100) * 104$

FALTAS $=(\operatorname{INT}(\operatorname{RANDOM}(0,3) * 100) / 30)$ 
GARRAFONES $=$ INT (RANDOM $(500,800,20000)-$ DESABASTO_DE_GARRAFONES)

GARRAFONES_ROTOS $=$ INT $(\operatorname{RANDOM}(0,3))$

LLEGADAS_TARDE $=(\operatorname{INT}(\operatorname{RANDOM}(0,4)) * 100) / 40$

MO = CAPACITACION+MOTIVACIÓN

MOTIVACIÓN = SINERGIA

PREPARAR_GARRAFONES_PARA_PASAR_A_FASE_DE _LLENADO $=$ GARRAFONES-GARRAFONES_ROTOS

PRODUCCION_DIARIA $=100+$ SALIDA

PRODUCTIVIDAD $=($ MO/PRODUCCION_DIARIA $) * 100$

ROTACION_DEL_PERSONAL_ = RANDOM $(0,0.2) *$ CONFLICTOS_CON_EL_PERSONAL

SINERGIA $=$ IF (ROTACION_DEL_PERSONAL $* 100 / 18)$ $<=40$ THEN (0) ELSE (1)

\section{Causal Assumptions}

We present the causal assumptions that arise for decision making within the company:

- $\quad$ The less water in tank 2 , the less water is pumped through 4 filters in tank 3 . If there is more water in tank 2 , more water is pumped through 4 filters in tank 3 .

If less water is pumped through 4 filters to Tank 3 there will be fewer jugs of water. If more water is pumped through 4 filters to Tank 3 there will be more jugs of water.

- If there is less water shortage there will be more water jugs, if there is more water shortage there will be less water jugs.

- If there are fewer jugs, less will go to the filling phase, if there are more jugs, more will go to the filling phase.

- $\quad$ If there are fewer broken jugs, more jugs will go to the filling phase, if there are more broken jugs, fewer jugs will go to the filling phase.

- $\quad$ If there are fewer broken jugs, there are fewer costs; if there are more broken jugs, there are more costs.

If there are less jugs in the filling phase, there will be less jugs filled, if there are more jugs in the filling phase, there will be more jugs filled.

If there are fewer faults there is more motivation, if there are more faults there is less motivation.

If there are fewer late arrivals there is more motivation, if there are more late arrivals there is less motivation.
If there are fewer late arrivals there are fewer discounts 2 , if there are more late arrivals there are more discounts2.

- If there are fewer absences there is more labour, if there are more absences there is less labour.

- $\quad$ If there are fewer absences there is more labour, if there are more absences there is less labour.

If there is less productivity there is more training, if there is more productivity there is less training.

- If there is less total production there is less productivity, if there is more total production there is more productivity.

If there is less labor there is less turnover, if there is more labor there is more turnover.

If there is less personnel turnover there is less synergy, if there is more personnel turnover there is more synergy.

- $\quad$ If there is less synergy there are more conflicts, if there is more synergy there are less conflicts.

If there are less conflicts there are less conflicts with the staff, if there are more conflicts there are more conflicts with the staff.

\section{STELLA Model}

With all the information gathered, the simulation model is made using the dynamic simulation software known as STELLA. The corresponding Forrester diagram is shown below (Figure 4).

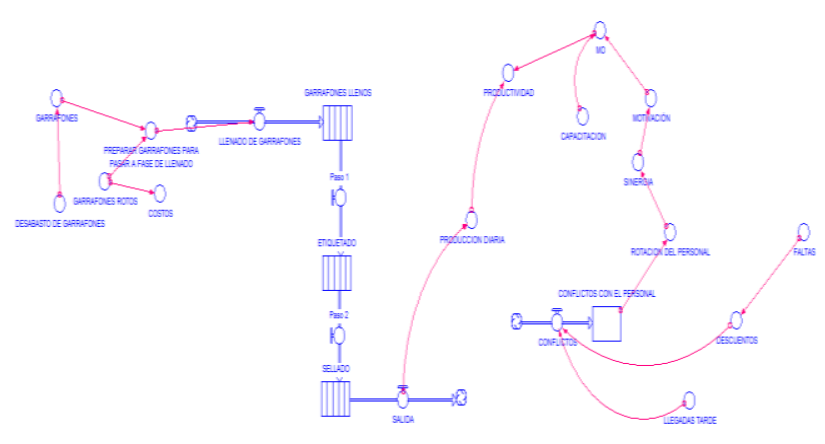

Figure 4 Forrester Diagram Source: Prepared by the authors

Once the model of the current system has been obtained, the evaluation is performed for its validation, finding the following results. The validation is carried out after 30 runs in the software, finding that the results obtained correspond to the behaviour pattern of the company's historical data (Figures 5 and 6). 


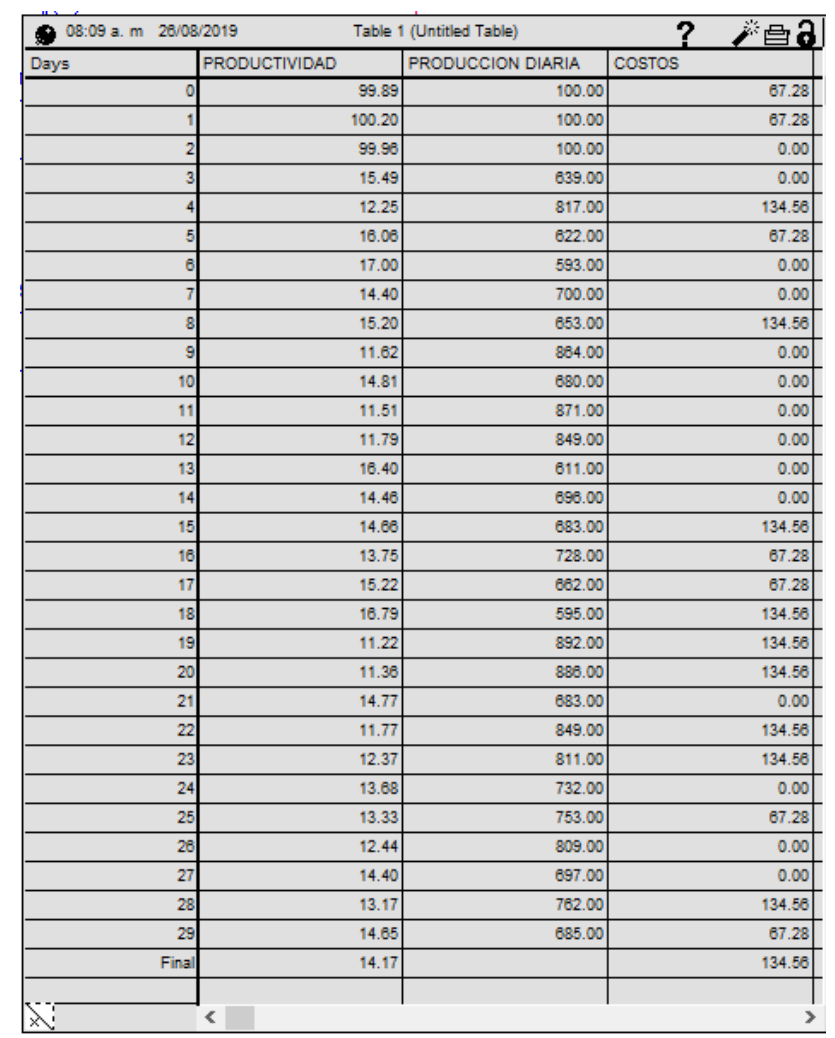

Figure 5 Program results

Source: Prepared by the authors in the STELLA software

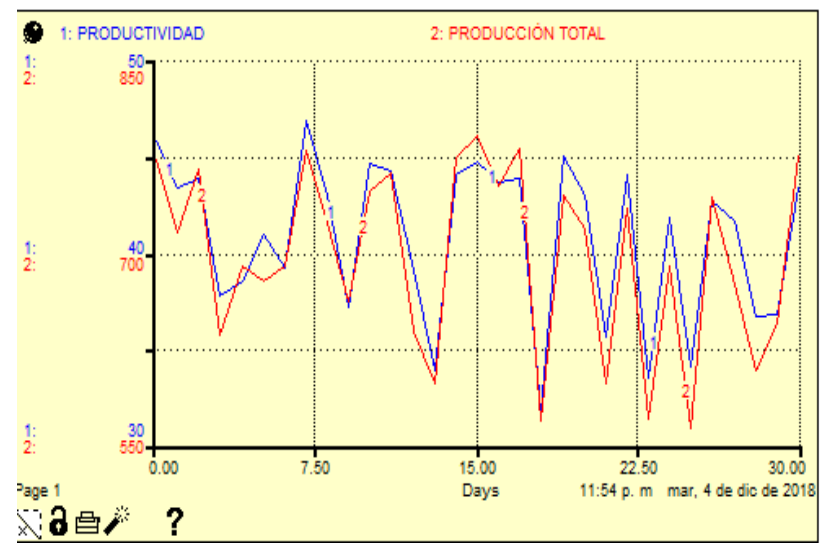

Figura 6 Resultados del programa

Source: Prepared by the authors in the STELLA software

Once we analyzed the data obtained after carrying out the simulation runs and observing the behaviour of the factors, it was concluded that the results do indeed show similarity with the data currently held in the company, according to the company's production (Figures 8 and 9).

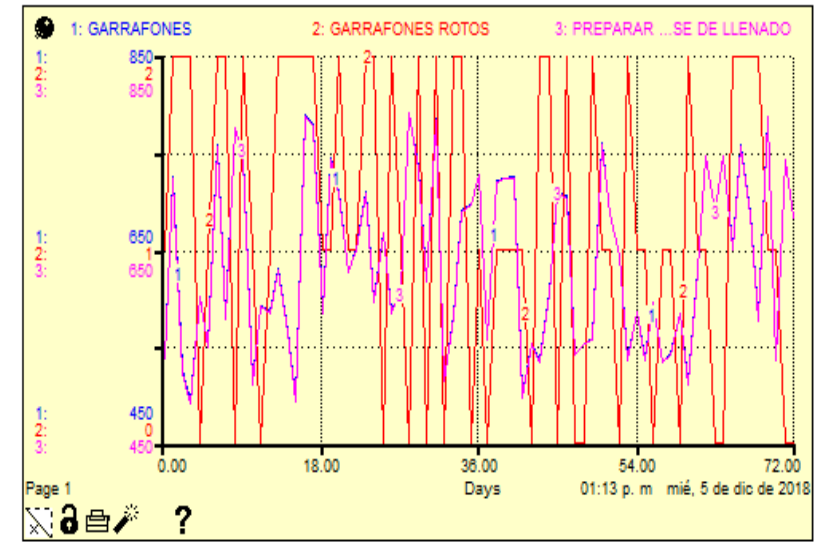

Figure 7 Actual Production Results

Source: Production Log

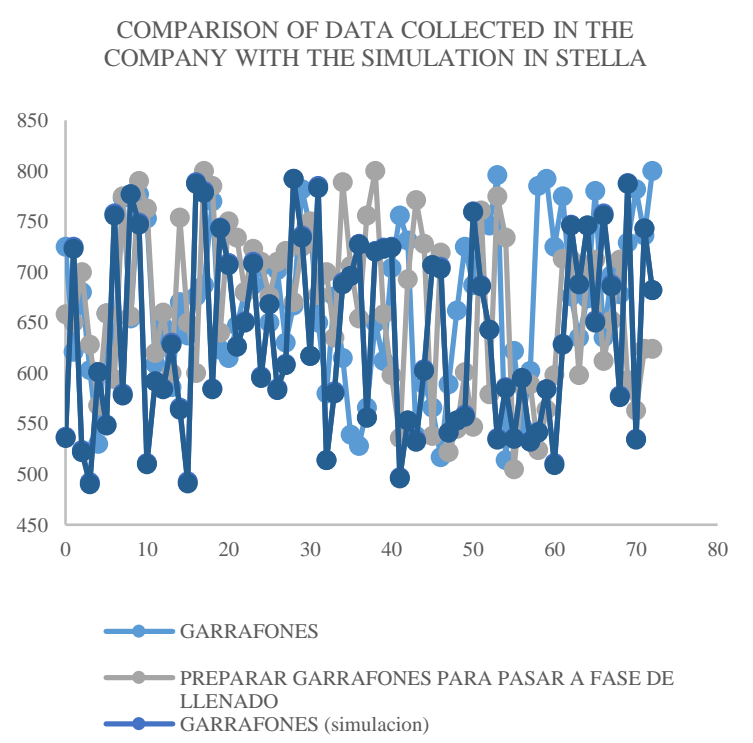

Figure 8 Software results

Source: Prepared by the authors with STELLA

It should be noted that the company produces empirical calculations and approximations regarding its sales forecasts. Similarly, with the validated model, we proceeded to experiment with possible proposals for improvement to assess what would be the impact on the most important factors to be evaluated by the model, productivity and total production of full jugs. The results are presented in Figures 9, 10, 11 and 12. The use of this tool will allow the evaluation of the probable results that can be given with the application of alternative policies that the company can implement. It allows for an approximation of the level of production and productivity that can be achieved by the company. 
SIMULATION OF CURRENT MODEL

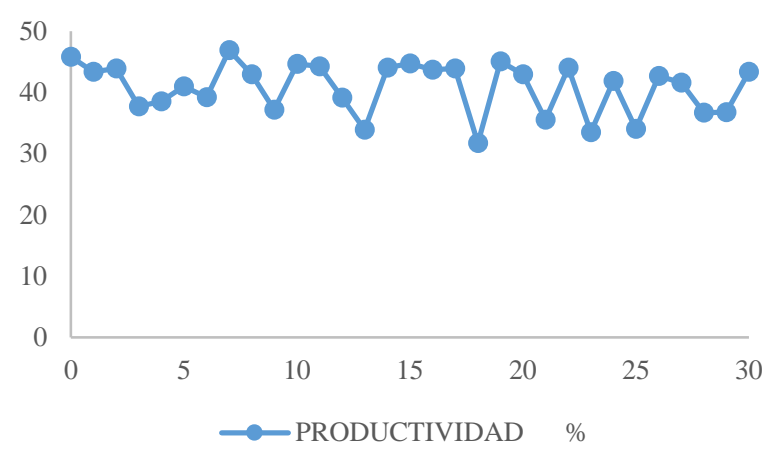

Figure 9 Simulation of current model Productivity Source: Prepared by the authors

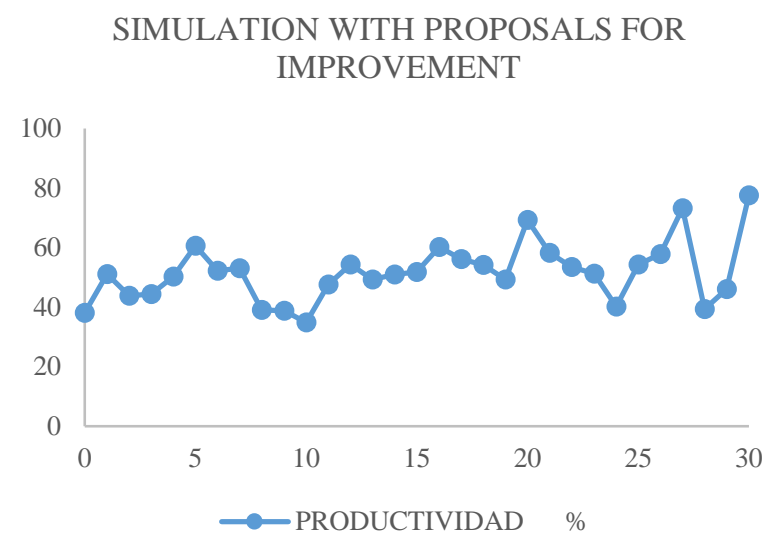

Figure 10 Improved model simulation Productivity Source: Prepared by the authors

\section{DATA COLLECTION IN THE} COMPANY

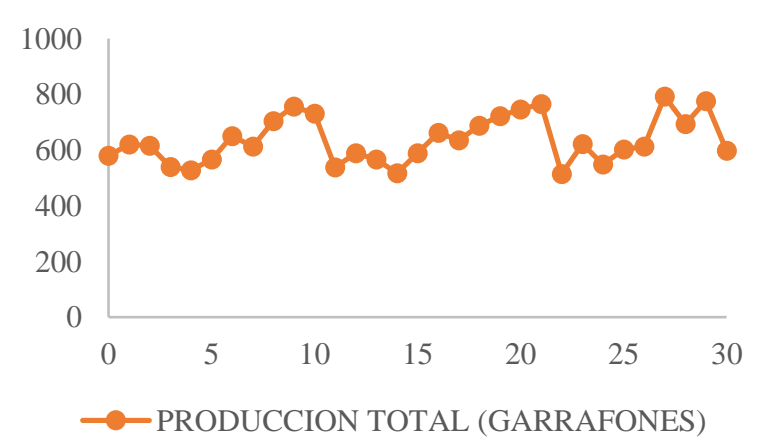

Figure 11 Simulation of the current model Production Source: Prepared by the authors
SIMULATION WITH PROPOSALS FOR IMPROVEMENT

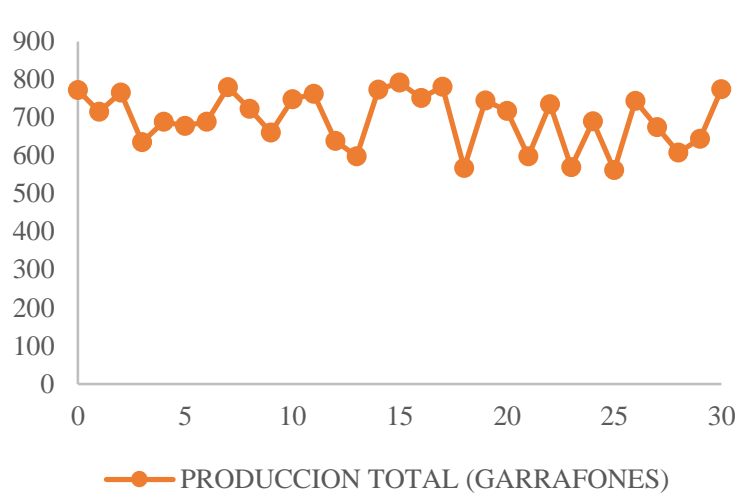

Figure 12 Improved Production Model Simulation Source: Prepared by the authors

\section{Conclusions}

This simulation tool contributes to improve the company and is of great help since it not only allows them to realize the possible consequences of the operational decisions with more detailed information, but also allows them to see the behavior of the two important factors for the company. The STELLA software allows them to make an analysis that improves decision making at the production, inventory, work environment, and productivity levels in the company, expecting better results that promote growth and job stability for the productive organization.

\section{References}

Baganha, M.P., Cohen M. (1998). the Stabilizing Effect of Inventory in Supply Chains. Operations Research, vol. 46, núm. 3, pp. S72S73.

B. Angerhofer, «System dynamics modeling in supply chain management: research review,» Proceedings of the 2000 Winter Simulation Conference, pp. 342-351, 2000.

Chandler, M., Boutilier, R. (1992). the development of dynamic system reasoning. Contributions to Human Development 21. pp. 121-137.

Feng, Y. (2009). Study on Model of Supply Chain Inventory Management Based on System Dynamics. International Conference on Information Technology and Computer Science. 
Forrester, J.W. (2006). System Dynamics: the Foundation under Systems thinking. Disponible en: http://sysdyn.clexchange. org/sdep/papers/D-4828.html.

Forrester, J.W. (1996). the Beginning of System Dynamics. Banquet Talk at the International Meeting of the System Dynamics Society, Stuttg [5] Jay W. Forrester.System Dynamics and K-12 teachers, A lecture at the University of Virginia School of Education, May 30.

Forrester, J.W. (1989). Learning through System Dynamics as Preparation for the 21st Century. Keynote Address for System Thinking andDynamic Modeling Conference for K-12 Education, Concord Academy, Concord, MA, USA, June 27-29, 1994 art, Germany, July 13.

Harris, J.K., Swatman, P.M.C. (1997). Efficient Consumer Response (ECR): a Survey of the Australian Grocery Industry. ACIS'97 - 8th Australasian Conference on Information Systems, Adelaida; pp. 137

J. W. Forrester, «Industrial Dynamics - After the first decade,» Institute for Operations Research and the Managment Sciences, vol. 14, $\mathrm{n}^{\circ}$ 7, pp. 398-415, 1968.

\section{J. Sterman, BUSINESS DYNAMICS,}

Massachusetts:

McGraw-Hill, 2000, p. 8-25.

J. C.-A. Hao Zhang, «A conceptual model for assisting sustainable manufacturing through system dynamics.,» Journal of Manufacturing Systems, 2013.

R. K. • R. K. Singh, «Study on Coordination Issues for Flexibility in Supply Chain of SMEs: A Case Study,» Global Journal of Flexible Systems Management, pp. 81-

92, 2012.

Sterman, J. (2000). Bussiness Dynamics: Systems thinking and Modeling for a ComplexWorld. Mcgraw-Hill.

Vo, H., V., Chae B., Olson D. (2007). Developing Unbounded Systems thinking: Using Causal Mapping with Multiple Stakeholders within a Vietnamese Company. The Journal of the Operational Research Society, Vol. 58, No. 5. pp. 655-668.
Z. J. P. Madani Alomar*, «Linking supply chain strategy and processes to performance improvement,» Variety Management in Manufacturing. Proceedings of the 47th CIRP Conference on Manufacturing Systems, pp. 628634, 2014.

Z. A. Nader Nada, «SERVICE VALUE CREATION CAPABILITY MODEL TO ASSESS THE SERVICE INNOVATION CAPABILITY IN SMEs,» 7th Industrial

Product-Service Systems Conference - PSS, industry transformation for sustainability and business, pp. 390- 395, 2015. 